but it has steadily declined, so that in 1938 it was 4,062,800. This has involved among other things difficult readjustments in educational facilities, especially elementary schools; for the decrease in elementary school children from 900,000 in 1915 to 543,000 in 1937 is very much greater proportionately than that in the total population. In this connexion it is interesting to note that, of the 50,000 children leaving elementary schools in 1937, 89 boys and 127 girls were described as of "super-normal" mental condition.

THE subject chosen in this volumo for special analysis is libraries. In the year ended March 31,1938 , $40,116,733$ boolss were issued to borrowers from public libraries in Greater London, and 20,175,088 from libraries maintained by local authorities in extra.London. In addition there were 2,078,559 issued from public libraries in extra-London under county council control. In the administrative county alone, issues of books have risen from 14,512,112 in 1928 to $19,941,654$ in 1938 , the number per registered borrower increasing from $29 \cdot 3$ to $31 \cdot 1$. For somo reason or other, Woolwich heads tho boroughs in respect of reading-as measured by use of public libraries-whilst St. Pancras is at the bottom of the list. Readers have $2,431,832$ books from which to choose, and they borrow three novels for every nonfiction work.

\section{Recent Comets}

AN I.A.U. telegram from Copenhagen announces that Comet Faye has been discovered by Jeffers at Harvard on November 3 at $4 \mathrm{~h}$. $1 \mathrm{~m}$. U.T. Its position is given as R.A. 20h. $13 \mathrm{~m} .28 \cdot 3 \mathrm{~s}$., S.Lec. $10^{\circ} 18^{\prime} 15^{\prime \prime}$, and it is described as diffuso with central condensa. tion. In the "Handbook of the British Astronomical Association", 1939, the elements and ephemeris of this comet have been computed by Messrs. WV. P. Henderson and P. J. Harris, who applied tho perturbations of Jupiter and Saturn. Perihelion passage is given as April 23, 1940, but it will be apparently half a day later. A comet was discovered by Frien at Harrard on November 4 at $13 \mathrm{~h} .30 \mathrm{~m}$. Its position is given as R.A. 16h. $52 \cdot 9 \mathrm{~m}$., N. Dec. $34^{\circ} 03^{\prime}$. The daily motion is $+7 \mathrm{~m}, 30 \mathrm{~s}$. in R.A. and $-10^{\prime}$ in Dec. It is described as diffuse without central condensation or nucleus. Fothing is stated about its magnitude.

\section{Engineers' Study Group on Economics}

Ax emergency programme to meet the difficulties occasioned by the war has been issued by the Engineers' Study Group on Economics. Consideration of the problems which followed the War of 1914-18 has led to the view that, while the first effort must be directed towards winning the present war, attention must be given in good time to plans for reconstruction, so that practical proposals may be ready when required. The Group has accordingly resolved to make a special study of reconstruction, dealing particularly with such problems as demobili- zation, industrial change-over, agricultural changes, international trade, paying for the war, etc. Those interested are asked to communicate with the Group at 35, Gordon Square, London, IV.C.I.

\section{Announcements}

Tre annual Huxley Memorial Lecture of tho Royal Anthropological Institute will be delivered on November 28, at 2.30 p.m., at 2 I Bedford Square, W.C.1, on "Charity and the Struggle for Existence", by Dr. R. R. Marett.

The Tilden Lecture of the Chemical Society will be delivered by Dr. L. E. Sutton on December 14, at 2.30 p.m. in tho Society's rooms. The title of the lecture will bo "The Present State of Valency Theory".

A PAPEn on the "Penetration of Rays through tho Skin and Radiant Energy for the Treatment of Wounds" will bo read by Sir Leonard Hill, at the Royal Society of Arts, on November 22 at 2.30 p.m. Applications for tickets should bo made to the Secretary, Royal Society of Arts, John Street, Adelphi, IV.C.2.

Tine following have been elected officers for 1940 of the Mineralogical Society : President, Mr. Arthur Russell ; Vice-Presidents, Prof. C. E. Tilley, Dr. WV. Campbell Smith; Treasurer, Mr. F. N. Ashcroft; General Secretary, Dr. G. F. Claringbull ; Foreign Secretary, Sir Thomas H. Holland; Editor of the Journal, Dr. I. J. Spencer.

TrE following appointments and promotions havo recently been mado in the Colonial Service: C. B. Johnston, chemist, Department of Science, Barbados ; F. H. Ormerod, agricultural superintendent, Gold Coast; V. D. Van Someren, zoologist, Central Veterinary Research Institute, Kenya; H. B. Vaters, director of agriculture, Kenya, director of agriculture, Gold Coast.

MLr. G. MI. Harvey, deputy electrical inspector of mines, has been appointed electrical inspector of mines, with effect from November 1 , in succession to Mr. J. A. B. Horsley. Mr. Horsley is undertaking special duties for the Mines Department during the war, more particularly in connexion with the organization of the electrical supplies required for the working of mines and quarries. Ho will also complete, so far as possible, the work in connexion with the revision of the existing code of srfety regulations for coal mines.

THE Geological Society of London announces that the eighteenth session of the International Geological Congress, which was to have been held in London during July 31-August 8, 1940, is postponed indefinitely. 